\title{
Den Stärkezucker in einen völlig rein schmeckenden, intensiv süssen, harten und dichtkörnigen, kry- stallisirten Zustand, dem gewöhnlichen Zucker ähnlich zu verăndern;
}

\author{
von Friedr. Anthon in Prag.
}

Verf. presst die durch Einwirkung der Schwefelsäure auf Stärke erhaltene, zuckerähnliche Substanz stark aus und (dies ist das Neue des Verfahrens) erwärmt die Masse, am besten im Wasserbade, bei $60-80^{\circ} \mathrm{R}$. so lange in offenen Gefässen, bis die Concentration $43-45^{0} \mathrm{~B}$. erlangt hat. Dann lässt man den geschmolzenen Zucker erkalten, wobei, je nachdem feineres oder gröberes Korn gewünscht wird, die Masse mehr oder weniger oft umgerührt wird. Bis zu $25-30^{\circ} \mathrm{R}$. abgekühlt, wird die Masse in Formen gefüllt, darin bis zum völligen Festwerden gelassen, dann herausgenommen und in gelinde geheizten Trockenstuben getrocknet. Ein Ablassen von Syrup findet nicht statt. (Die neuesten Erfindungen. 1863. S. 108. - Polyt. Centralbl. 1863. Lief. 17. S. 1181.) Bkb.

\section{Nachweisung des Traubenzuckers.}

Um Traubenzucker von Rohrzucker zu unterscheiden, empfiehlt Neubau er die Mulder'sche Methode mittelst einer Indigolösung. Nach ihm soll man folgendermaassen verfahren: die auf Zucker zu prüfende Flüssigkeit färbt man mit neutraler Indigolösung schwach blau, setzt eine Lösung von kohlensaurem Natron tropfenweise bis zur schwach alkalischen Reaction binzu und erhitzt einige Secunden zum Kochen. Sieht man jetzt durch die Flüssigkeit nach einer weissen Wand, so bemerkt man bald, dass das Blau allmälig in Violet übergeht, welches endlich einer gelben Nüance weicht. Beim Bewegen der Mischung wird durch die Berührung mit dem Sauerstoffe der Luft sebr bald die violette und endlich auch die blaue Farbe wieder eintreten, die in der Ruhe meistens zum zweiten Male in Gelb übergeht. In dieser Weise lassen sich noch 0,5 Milligrm. Traubenzucker in $5 \mathrm{C}$. C. Flüssigkeit nachweisen, während jedoch die Fehling'sche Reaction noch mit aller Sicherheit 0,2 Milligramm Zucker in 5 C.C. Flüssigkeit entdecken lässt. (Zeitschr. fuir analyt. Chemie. Jahrg. 1.)

$B$. 